\title{
CHEMICAL, CLINICAL, AND IMMUNOLOGICAL STUDIES ON THE PRODUCTS OF HUMAN PLASMA FRACTIONATION. XXXIV. COMPARATIVE STUDIES ON THE NUTRITIVE VALUE OF ORALLY AND INTRAVENOUSLY ADMINISTERED HUMAN SERUM ALBUMIN IN MAN 1, 2,
}

\author{
BY RICHARD D. ECKHARDT, JESSICA H. LEWIS, T. LYNCH MURPHY, \\ WILLIAM H. BATCHELOR, AND CHARLES S. DAVIDSON \\ (From the Thorndike Memorial Laboratory, Second and Fourth Medical Services [Harvard], \\ Boston City Hospital, and the Department of Medicine, Harvard Medical School, Boston)
}

(Received for publication March 25, 1947)

Human serum albumin for therapeutic use was developed and produced during the war as a colloid of high osmotic properties, chiefly for the treatment of shock. Its usefulness in this regard has been attested by several workers ( 1 to 3 ). In addition, the use of concentrated albumin solutions has been studied in chronic Bright's disease $(1,4)$, and in cirrhosis of the liver $(1,5)$. In both these conditions therapy was directed at increasing the serum albumin concentration and promoting diuresis.

When a protein is administered either orally or parenterally as a partial or a complete source of nitrogen for an individual, care must be taken that its nutritional adequacy is known. In this regard there are 2 important considerations : (1) Does the protein contain all the essential amino acids in optimal amounts; and (2) is the protein readily available for the metabolic needs of the body?

In answer to the first, human serum albumin has been shown to contain a low concentration of tryptophane (6), and, in rat growth experiments, fortification with both tryptophane and isoleucine was required to obtain optimum growth (7). No

1 This is paper No. 57 in the series, "Studies on Plasma Proteins," from the Harvard Medical School, Boston, Mass., on products developed by the Department of Physical Chemistry from blood collected by the American Red Cross.

2 This study was aided in part by a grant from the Abbott Laboratories, North Chicago, Ill.

8 The albumin administered intravenously was obtained in part from the Bureau of Medicine and Surgery, U. S. Navy Department, and in part was specially prepared by the Plasma Fractionation Laboratory, Harvard Medical School, under a contract recommended by the Committee on Medical Research, between the Office of Scientific Research and Development and Harvard University. The albumin administered orally was supplied by the Medical Research Division, Sharp and Dohme, Inc., Glenholden, $\mathrm{Pa}$. supplementation was required for the dog. These studies indicate that human albumin may be deficient in 2 of the amino acids essential to man (8).

As for the second question, the ready availability for metabolism of parenterally administered plasma proteins has been the subject of discussion and recent investigation. There have been observations by several investigators that following the intravenous injection of whole protein (plasma protein, whole blood and plasma albumin) there is a rise in plasma protein, a minimum excretion of nitrogen in the urine, and a positive nitrogen balance. This would suggest that whole protein parenterally administered was not as rapidly metabolized as whole protein given by mouth or hydrolyzed protein by vein. Thus, a rise of the plasma albumin concentration in patients with cirrhosis of the liver immediately following the administration of human albumin intravenously was observed by Thorn et al. (5). Browne et al. (9) found intravenously administered plasma would maintain a positive nitrogen balance in the "catabolic period" after damage in man, but that a protein hydrolysate given in similar amounts was almost quantitatively excreted as urea nitrogen. Elman and Davey (10) observed that plasma transfusions would correct the hypoalbuminemia of protein-depleted dogs, although in the period following this therapy the temporarily elevated plasma albumin dropped to its previous low level and much of the plasma protein nitrogen retained appeared in the urine. Albright (11) has shown that following the intravenous administration of plasma protein, "burning" and "conversion" of the protein did not start to an appreciable degree until at least the third post-injection day (at which time urinary nitrogen excretion increased and urinary phosphorous and potassium excretions decreased), and that the nitrogen excretion from the injected plasma was not 
complete in the subsequent 1 to 3 weeks. Approximately 50 per cent of the injected plasma protein was eventually burned and the remainder converted into tissue protein. Whole blood and plasma albumin behaved in a manner similar to blood plasma. During plasma transfusions in man, Meyer et al. (12) noted a decrease in the urinary nitrogen excretion which resulted in a marked positive nitrogen balance, but 13 per cent, 87 per cent, and 50 per cent of the "retained" nitrogen were subsequently excreted in the urine. However, Whipple and co-workers (13) have never observed a significantly increased excretion of urinary nitrogen following plasma infusions in dogs, even when the dogs were rendered diabetic with phlorhizin (14).

In an attempt to answer the questions of the nutritional adequacy and availability of intravenously and orally administered albumin in man, the studies reported here were made. Five healthy young males in good nutritional status were placed on a diet almost devoid of protein, but thought to be adequate in calories and vitamins. Protein was supplied either orally as lactalbumin ${ }^{4}$ or human albumin, or intravenously as partially hydrolyzed (enzymatic) casein $^{5}$ or as human albumin solu-

4 "Essenamine" furnished by Frederick Stearns \& Co., Detroit, Michigan.

s "Amigen" furnished by Mead Johnson \& Co., Evansville, Indiana. tion. The actual volume of each of the solutions and also the amount of powdered lactalbumin to be administered were determined from the nitrogen content by macro-Kjeldahl analysis of each. Daily nitrogen balance was followed. Hematocrit, plasma volume, and plasma protein concentration were determined at suitable intervals.

\section{METHODS}

\section{A. Protein-free diet}

A diet designed to provide from 3000 to 3300 calories daily with a minimum nitrogen intake was modified from that used by Rose (8). The diet is presented in Table I. ${ }^{\circ}$ Samples of each food used in this diet were analyzed by the macro-Kjeldahl procedure and it was found that the total nitrogen contained in the daily food intake was 0.3 gram for the first 2 individuals and $0.1 \mathrm{gram}$ for the final 3. A salt mixture was not provided, nor were vitamins which were not included in the vitamin capsule. We do not believe that these deficiencies were serious, except perhaps for the salt loss which probably took place during the periods of diarrhea in 2 individuals who took albumin orally. Nitrogen equilibrium or slight positive balance and constant weight have been obtained with this diet using purified casein (Labco) as the sole source of nitrogen.

6 The authors wish to thank Mrs. Elizabeth Caso, Instructor in Nutrition, Harvard School of Public Health, for advice in preparing this diet, and Miss Florence A. Packman, Director of Home Economics of the Spry Kitchen of Lever Brothers Company, Cambridge, Massachusetts, for developing and testing the recipe used for the cornstarch cookies.

TABLE I

\begin{tabular}{|c|c|c|c|}
\hline & Carbohydrate & Nitrogen & Fat \\
\hline $\begin{array}{l}\text { Cornstarch pudding } \\
88 \mathrm{gm} . \text { hard candy } \\
400 \mathrm{cc} \text {. ginger ale } \\
119 \mathrm{gm} \text {. "beta lactose" } \\
51 \mathrm{gm} \text {. centrifuged butter } \\
6 \mathrm{cornstarch} \text { cookies } \\
60 \mathrm{gm} \text {. currant jelly } \\
360 \mathrm{cc} \text {. coca cola } \\
300 \mathrm{cc} \text {. lemon juice* } \\
60 \text { gm. canned pear (juice pack) } \\
1 \text { "dayamin" } \dagger \text { vitamin capsule }\end{array}$ & $\begin{array}{r}\text { grams } \\
93.8 \\
88.0 \\
37.8 \\
119.0 \\
\\
87.6 \\
39.6 \\
43.0 \\
29.4 \\
4.8\end{array}$ & $\begin{array}{l}\text { grams } \\
\text { None } \\
\text { None } \\
\text { None } \\
\text { Not measured } \\
0.001 \\
0.026 \\
0.016 \\
0.012 \\
0.190 \\
0.021 \\
0.016\end{array}$ & $\begin{array}{r}\text { grams } \\
30.0 \\
\\
51.0 \\
19.8\end{array}$ \\
\hline $\begin{array}{c}\text { Total } \\
1.8 \mathrm{gm} \text {. protein } \\
\text { and } \\
3089 \text { calories }\end{array}$ & 543.0 & 0.282 & 100.8 \\
\hline
\end{tabular}

* In part of the study a synthetic lemon powder was substituted for the lemon juice, reducing the nitrogen intake by $0.19 \mathrm{gm}$.

† Furnished through the courtesy of Abbott Laboratories, North Chicago, Ill., and containing per capsule: Thiamine hydrochloride $5 \mathrm{mgm}$., riboflavin $5 \mathrm{mgm}$., nicotinamid $25 \mathrm{mgm}$., pantothenic acid 5 mgm., pyridoxine $1.5 \mathrm{mgm}$., ascorbic acid 100 mgm., vitamin A 10,000 U.S.P. units, vitamin D 1000 U.S.P. units. 


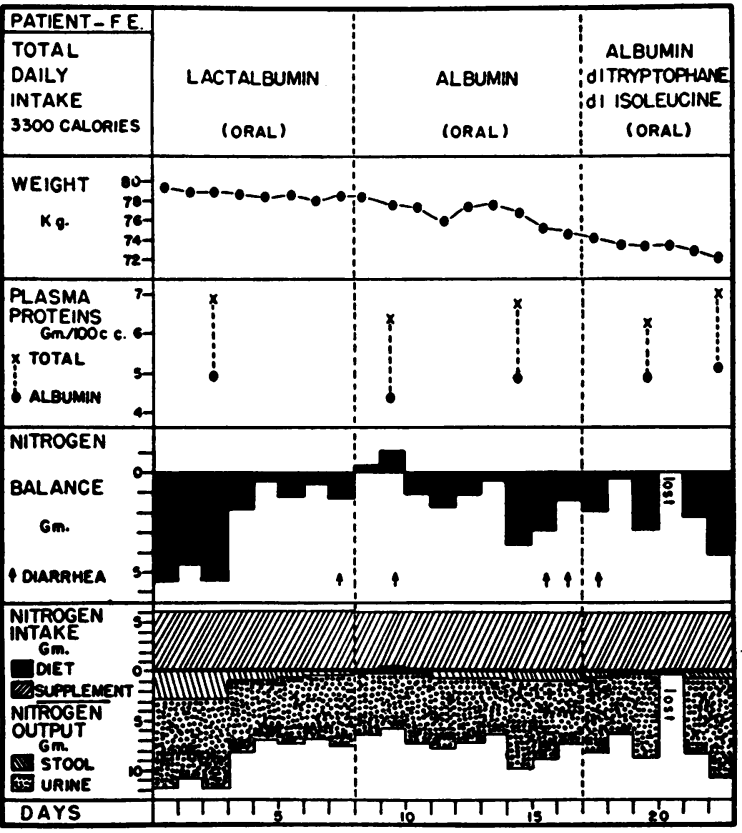

FIG. 1

\section{B. Biochemical methods}

The daily urine and pooled-stool nitrogen and total plasma protein were determined by micro- or macroKjeldahl digestion and subsequent nesslerization. Plasma albumin and globulin separations were made in part on the electrophoresis apparatus of Tiselius ${ }^{7}$ and in part by Howe precipitation (15). Blood volume measurements were made by the method described by Gregerson (16). Urinary tryptophane excretion was determined by the method of Shaw and McFarlane (17). Urinary alpha amino nitrogen determinations were by the gasometric ninhydrin method described by Van Slyke, MacFadyen and Hamilton (18).

\section{RESULTS}

The results will be divided into 3 parts; first, the 3 subjects to whom all protein was given by mouth; second, the 2 subjects to whom all protein was given intravenously; and third, the subject who received protein both orally and intravenously. There were no reactions to the intravenous administration of the albumin or the casein hydrolysate except once when the latter was given too rapidly and the individual became nauseated.

7 The authors express their appreciation to Dr. S. Howard Armstrong, Jr., Department of Physical Chemistry, Harvard University, for these determinations and their interpretation.

\section{Protein administered orally (Figures 1,2 and 3)}

Two subjects (F.E. and J. A.) were given during the first period lactalbumin orally to supply 37.5 grams of protein for 7 days in one, and for 8 days in the other. Albumin solution equivalent to 37.5 grams of protein was then substituted for the lactalbumin for 14 and 15 days, respectively, supplemented with 2.0 grams of dl-isoleucine ${ }^{8}$ and 2.0 grams of dl-tryptophane ${ }^{8}$ for the final 6 days. The daily protein intake was approximately 0.5 gram per kilogram of body weight. During the entire study of these subjects, both during lactalbumin and albumin administration, the excretion of nitrogen was greater than the intake by between 1.0 to 3.0 grams, except during the first 2 or 3 days when negative nitrogen balance was more marked, reflecting the previous high protein diet. When tryptophane and isoleucine were added to the diet during the period of albumin administration, there was no significant change in nitrogen excretion or balance. Both subjects noted weakness, had moderate intermittent diarrhea and nausea, and gradually lost weight $(6 \mathrm{kgm}$.

${ }^{8}$ Supplied by Merck \& Co., Inc., Rahway, N. J.

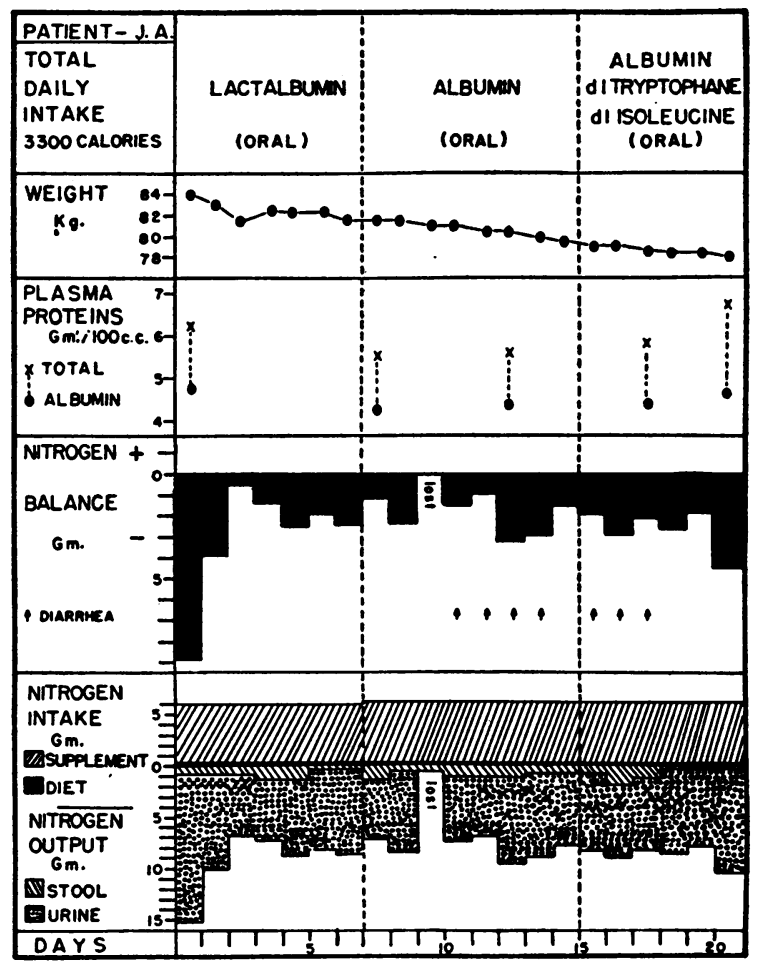

Fig. 2 
TABLE II

Relation between protein administered as hydrolysate, lactalbumin, and albumin orally and intravenously and the nitrogen excreted

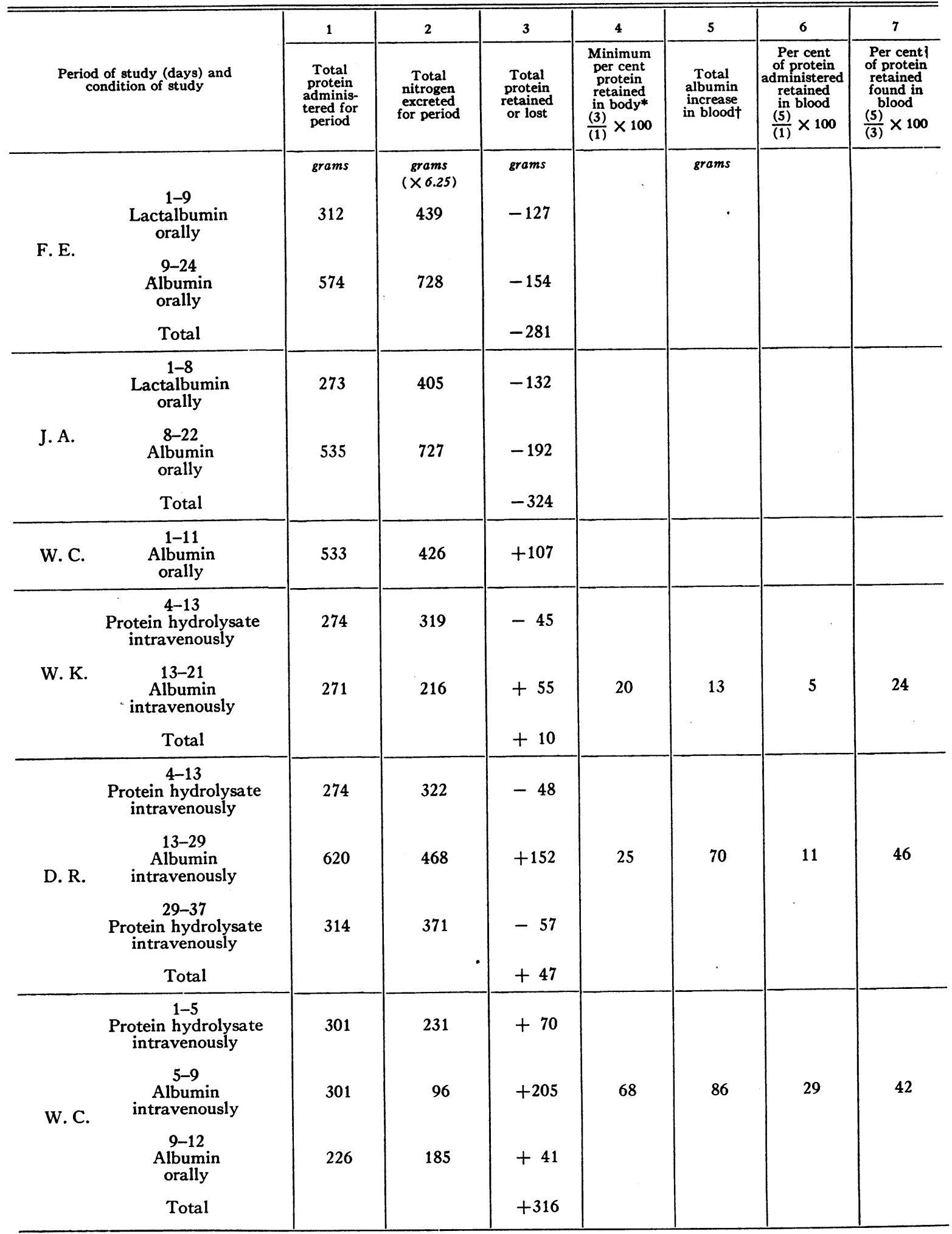

* Assuming all nitrogen excreted came from administered albumin.

† Calculated from plasma volumes and plasma albumin concentrations (Table III, column 6.) 


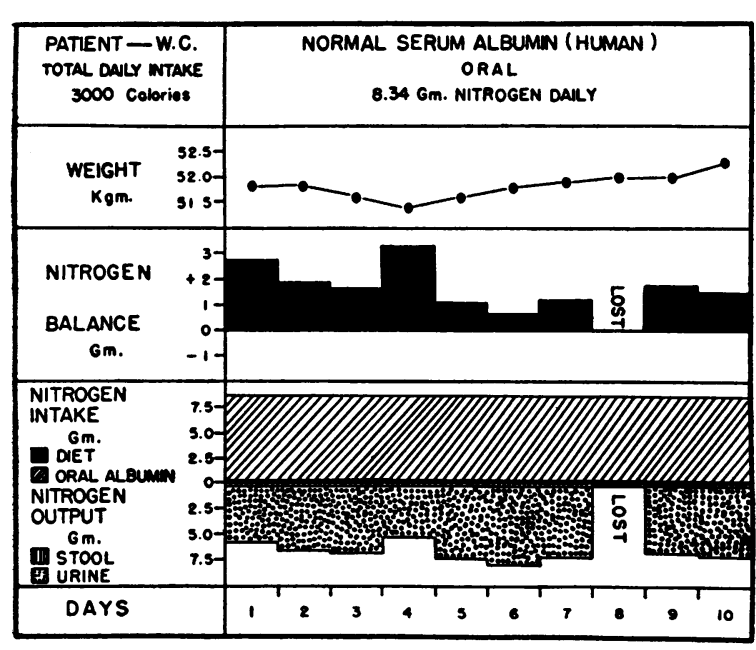

Frg. 3

and $7 \mathrm{kgm}$.) during the study, although both noted a prompt return of their sense of well-being, had normal bowel function, and regained much of their lost weight within 3 to 4 days after the study was discontinued and a normal diet was taken. Cumulative negative nitrogen balances for these subjects represent about 280 and 325 grams $(\mathrm{N} \times 6.25)$ protein loss from the body tissues (Table II, column 3). There was no significant change in plasma albumin concentration or hematocrit except during periods of probable mild dehydration associated with diarrhea.

In contrast to the 2 individuals just cited, the third (W. C.) received 50.0 grams of normal human serum albumin orally daily as the sole source of nitrogen. He remained in slight positive nitrogen balance throughout, gained slightly in weight, and felt entirely well during the 10-day study period. No tryptophane or isoleucine supplements were given.

\section{Protein administered entirely intravenously (Figures 4 and 5, Table III)}

Two subjects (W. K. and D. R.) were also given 37.5 grams of protein daily, this time intravenously in all experimental periods, again in amounts of about 0.5 gram per kilogram of body weight. Casein hydrolysate was given during the first period of 9 days, followed by human serum albumin for 16 days in one, and only 8 days in the other subject who became ill so that the study was discontinued (acute prostatitis). The sub- ject who continued for 16 days on albumin was given intravenously 2.0 grams of dl-tryptophane and 2.0 grams of dl-isoleucine with the albumin during the last 6 days, and followed by a final period of 37.5 grams of the casein hydrolysate daily for 8 days.

After a brief period of negative nitrogen balance on the protein-free diet, intravenous casein hydrolysate administration was begun and approximate nitrogen equilibrium was soon achieved. A postive nitrogen balance of significant degree was obtained (except for occasional days) during the 8 and 9 days of the administration of unsupplemented albumin. The individual (D. R.) who continued albumin administration, this time supplemented with tryptophane and isoleucine, continued to exhibit a positive nitrogen balance, although in this instance perhaps somewhat less marked. Slight but persistent negative nitrogen balance was obtained in this subject during the final 8-day casein hydrolysate period. After this period, the subject ate very well of a normal diet containing at least 100 grams of protein daily.

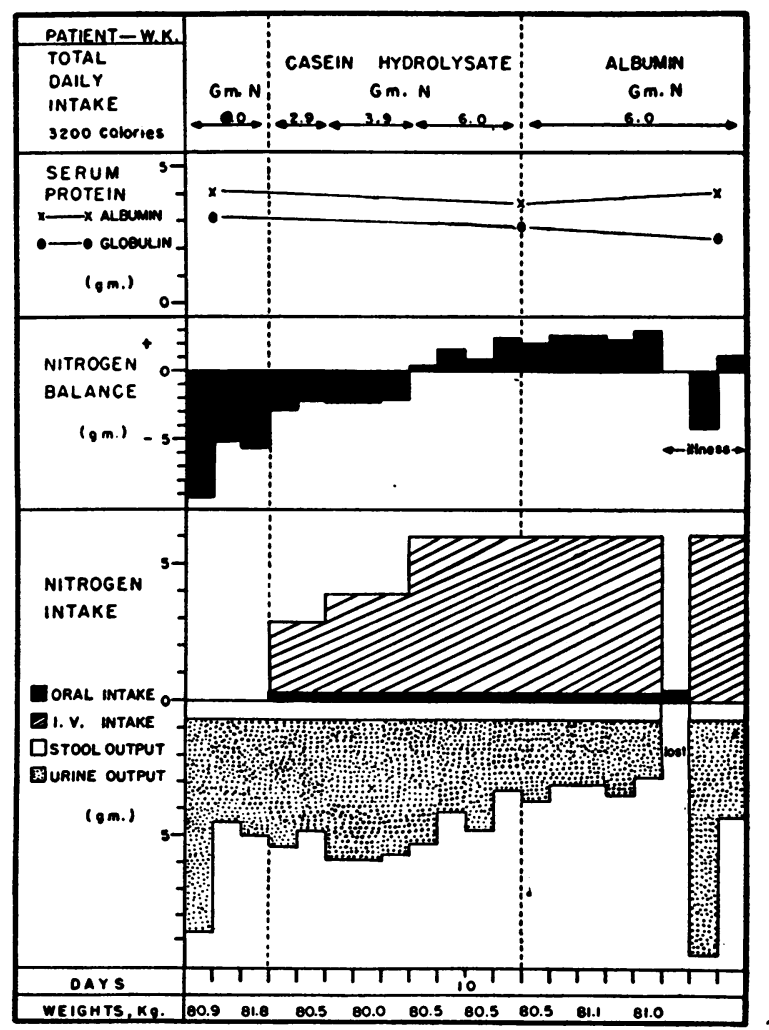

FIG. 4 


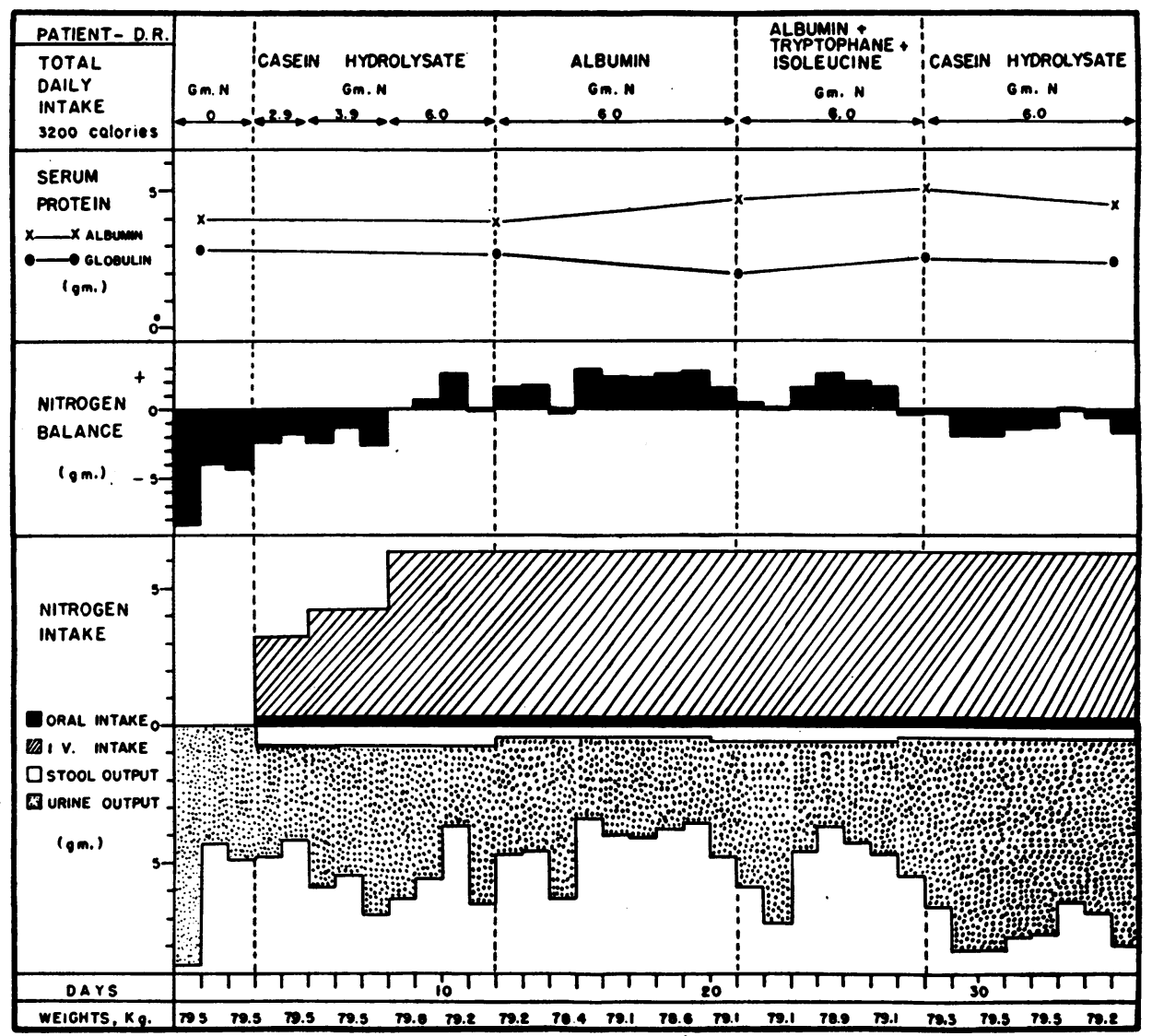

FIG. 5

The plasma albumin concentration remained the same in the individual (W. K.) given only 8 days of albumin, but rose progressively in the other during the 16 days of albumin administration, and subsequently fell to the control value by 24 days after albumin administration was discontinued.

An increase in plasma volume was observed after both the administration of casein hydrolysate and albumin (Table III, column 4). This is most clearly seen in subject D. R., in whom the plasma volume decreased again somewhat after the normal diet had been resumed. Hematocrit determinations in both decreased as the blood volume rose. This was most evident in D. R. at the end of the period of albumin administration.

There was an increase in the total circulating albumin during the period of albumin administration which was slight in subject W. K., but was striking in subject D. R. (Table III, column 5). In Figure 6 are plotted the values in this subject for the total increase or retention of albumin in the plasma determined at the conclusion of the albumin administration and the decreasing values at intervals thereafter (Table III, column 6). These values fall on a 6-day 50 per cent disappearance curve, calculated from the general equation of decay. ${ }^{9}$ In this subject, therefore, one-half of the plasma albumin retained during the period of albumin administration had disappeared from the plasma in 6 days, one-half of the remaining "extra" albumin during the next 6 days, et cetera,

- General Equation of Decay: $A=A_{0} e^{-k t}$, where $A=$ quantity of albumin retained in the plasma at any time, $t$, following the cessation of intravenous albumin infusions; $A_{0}=$ quantity of albumin retained in the plasma at the conclusion of the albumin administration; $t=$ time in days after cessation of infusions; $k=\frac{0.6932}{t}=0.1733$ (50 per cent decay in 4 days), 0.1386 (50 per cent decay in 5 days), and 0.1155 ( 50 per cent decay in 6 days). The values are plotted in Figure 6 as Decay Coefficients $\left(\frac{A}{A_{0}}\right)$ by rearranging the formula so that $\frac{A}{A_{0}}=e^{-k t}$. 
TABLE III

Plasma volume and protein values in three subjects given albumin intravenously

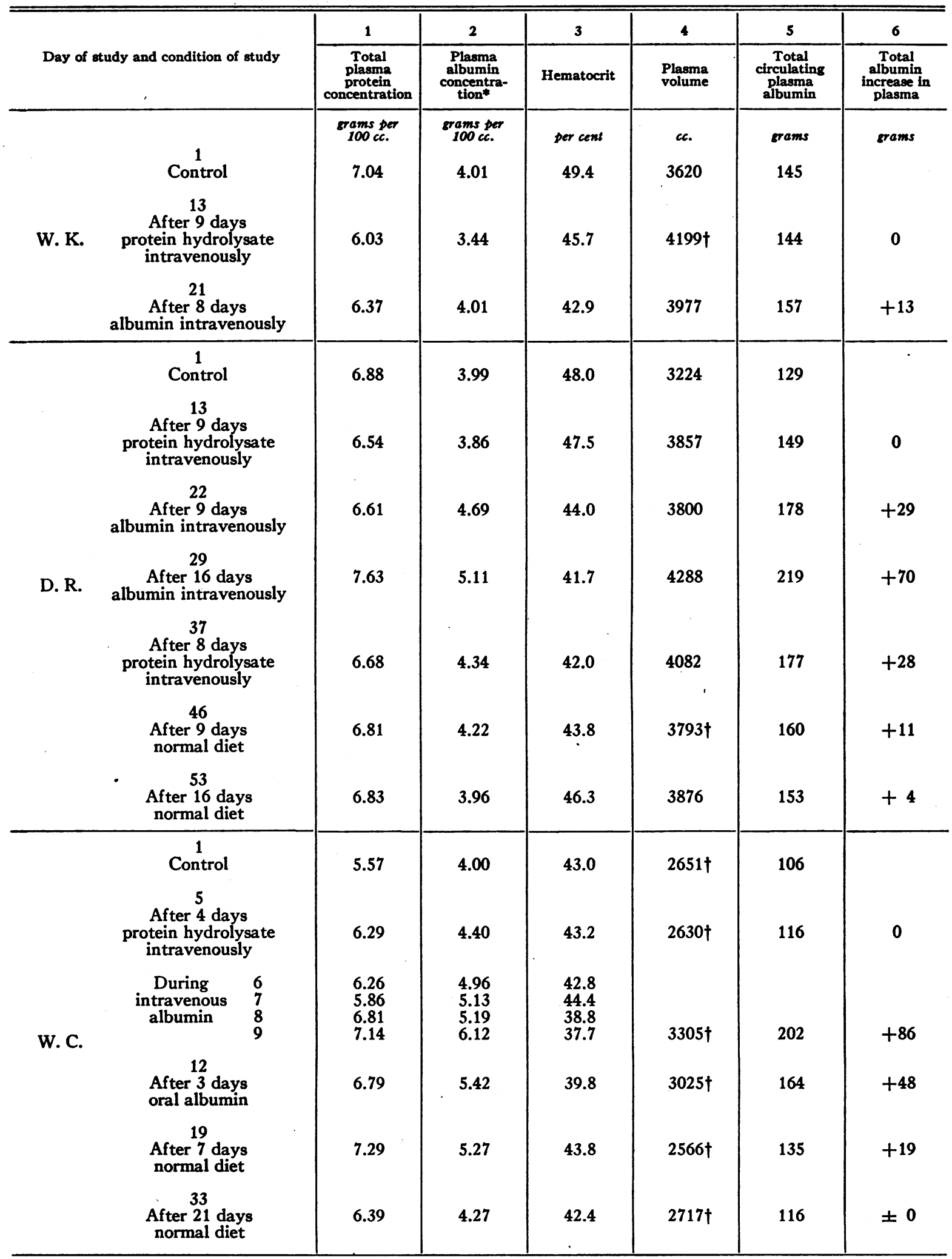

* Albumin and globulin separations by electrophoresis (W. K. and D. R.) and by Howe precipitation (W. C.).

$\uparrow$ Calculated from. changes in hematocrit-red blood cell volume assumed constant. 


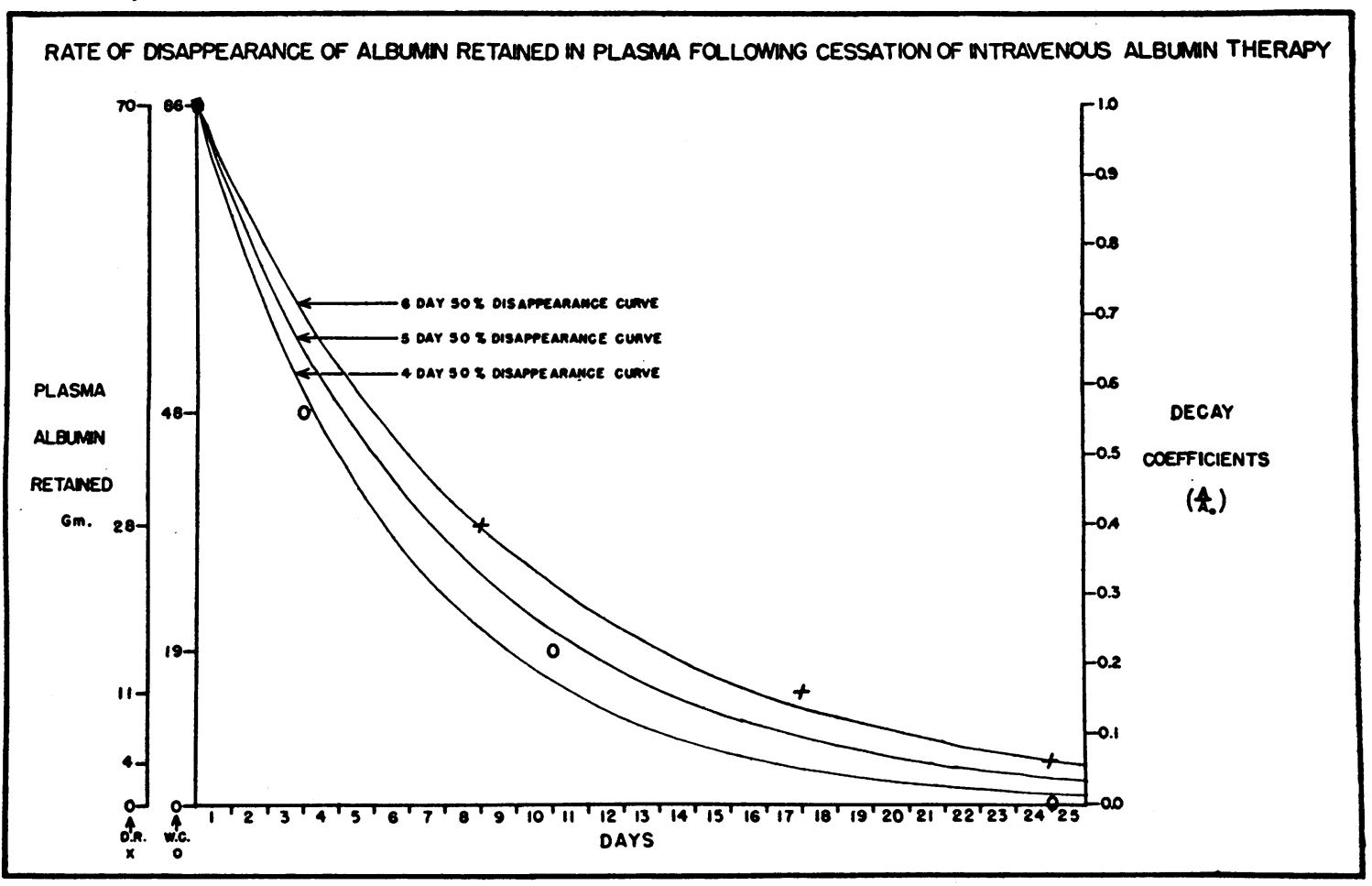

FIG. 6

so that by 24 days following the cessation of albumin administration the total circulating albumin had fallen to nearly the original value.

During the first period of casein hydrolysate administration, the subjects excreted somewhat more nitrogen (in terms of protein) than was administered (Table II, column 3). This is accounted for largely by the time required for approximate nitrogen equilibirium to be reached with the stepwise increase in hydrolysate administration (Figures 4 and 5). In contrast, during the period of albumin administration, both subjects retained at least 20 per cent of the protein administered



Fic. 7a
(Table II, column 4). Of the protein retained, 24 per cent and 46 per cent, respectively, was accounted for by increase in the plasma albumin (Table II, column 7). During the final period of casein hydrolysate administration, subject $D$. $R$. excreted slightly more nitrogen than was given.

Urinary tryptophane excretion was-essentially normal (Figure 7a and 7b) until D. R. received the albumin supplemented with dl-tryptophane, 2 grams daily for 8 days. During these 8 days he excreted an excess of 5.16 grams. The quantity of casein hydrolysate used contains about 375 mgm. of 1-tryptophane. It is apparent that only a small fraction of this tryptophane was excreted.

\section{Protein administered both orally and intra- venously (Figure 8, Table II)}

In contrast to the period during which the 4 individuals received a small amount of protein (37.5 grams) daily, either orally or intravenously, and the one who received orally a moderate amount (50.0 grams) daily is another study during which the latter subject (W. C.) was given 75.0 grams daily. During the first period of 4 days when the protein was supplied intravenously as casein hydroly- 


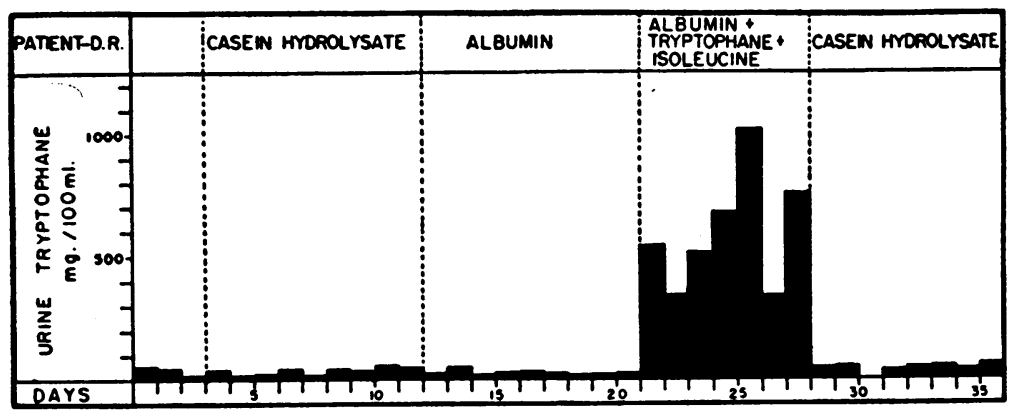

FIG. $7 b$

sate, the subject maintained a slight positive nitrogen balance amounting to 70 grams of protein for the period (Table II, column 3 ). There was a small rise in plasma albumin concentration. Of the nitrogen excreted daily during this period 0.28 gram was "free" alpha amino nitrogen, and 1.3 grams were "polypeptide nitrogen" determined as alpha amino nitrogen after hydrolysis of the urine. This amount of "polypeptide nitrogen" represents approximately 45 per cent of the polypeptide alpha amino nitrogen administered.

The day intravenous albumin was substituted for the casein hydrolysate, nitrogen excretion fell to approximately 3 grams per day, making the nitrogen balance about 8 grams positive per day, and totaling 205 grams of protein for the period (Table II, column 3). During this period there was a selective rise in the plasma albumin concentration of 1.72 grams per $100 \mathrm{cc}$. Plasma volume measurements were not satisfactory in this patient, but, assuming an unchanged red cell volume, it is possible to calculate the rise in plasma volume from the observed fall in hematocrit. Using these assumptions, roughly 40 per cent of the albumin retained was in the blood (Table II, column 7).

Nitrogen excretion during these 4 days represented 96 grams of protein. This would account for about 30 per cent of the albumin administered (301 grams) had it all come from this source, but if it is assumed that such a low nitrogen excretion is largely from "endogenous" protein catabolism, then up to 100 per cent of the albumin administered was retained (Table II). Thus, between 70 per cent and 100 per cent of the albumin administered was retained in the body, the greatest amount being extravascular and roughly 30 per cent in the blood plasma (Table II, column 6).
When an equivalent amount of albumin was given by mouth during the next 3 days, nitrogen excretion rose progressively so that on the third day approximate equilibrium was obtained. On the last day of the intravenous albumin administration and the first day that it was given orally there was slight proteinuria, 1.19 and 4.69 grams of protein, respectively.

The disappearance rate of the retained plasma albumin was somewhat more rapid in this subject than in subject D. R. The values for the total albumin increase (retention) in the plasma (Table

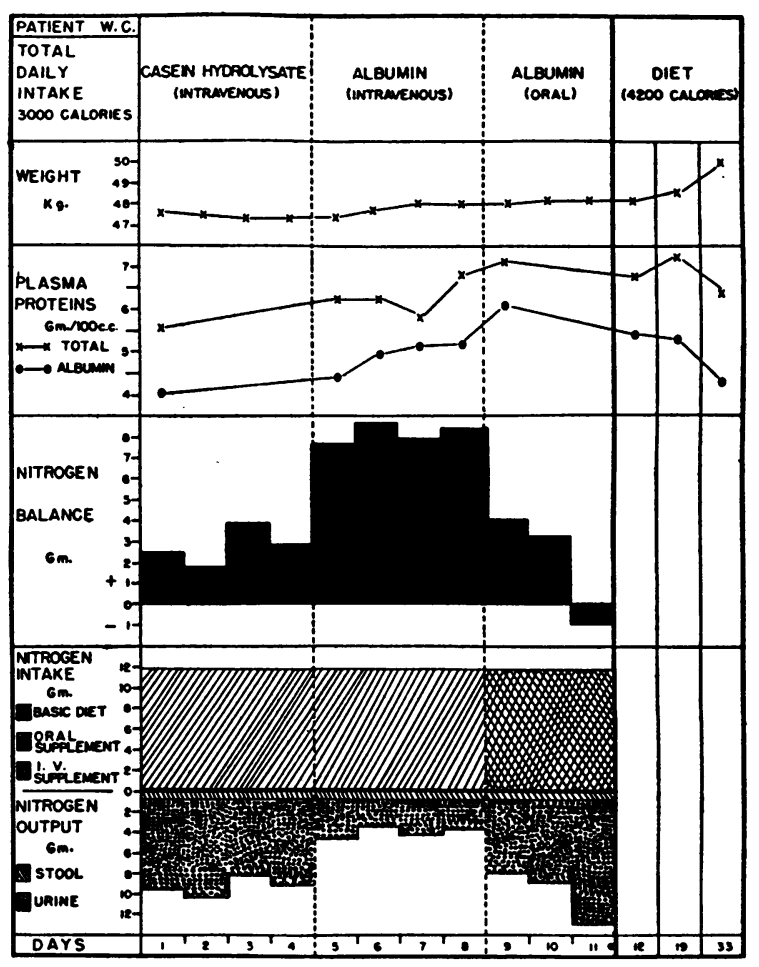

Fic. 8 
III, column 6) determined at the conclusion of the intravenous albumin administration and the decrease at varying intervals thereafter roughly fall on a 4-day 50 per cent disappearance curve (Figure 6). The total circulating plasma albumin had returned to its original value approximately 3 weeks after the intravenous albumin therapy was discontinued.

\section{DISCUSSION}

A sufficient amount of a single complete protein as a sole source of food nitrogen in a normal healthy subject should maintain nitrogen equilibrium if the caloric intake is high enough to prevent utilization of protein for energy. The first 2 subjects reported here were in negative nitrogen balance throughout while receiving 37.5 grams of human albumin by mouth. The failure to maintain nitrogen equilibrium was apparently not due to the low content of tryptophane and isoleucine in human albumin $(6,7)$ since the addition of adequate amounts of these 2 amino acids did not change the nitrogen excretion. Because the third subject maintained a slight positive nitrogen balance on 50.0 grams of unsupplemented albumin by mouth (representing almost twice the quantity of protein per kilogram of body weight in view of this subject's small stature), it is suggested that the previous individuals received an insufficient quantity of protein. This quantitative deficiency is further borne out by the fact that neither subject reached true nitrogen equilibrium on the same amount of the presumably complete lactalbumin during the control period. The 37.5 grams of protein (albumin or lactalbumin) given these 2 subjects daily furnished slightly under 0.5 gram of protein per kilogram of body weight which borders on the minimum requirement (19). However, normal active individuals should theoretically maintain nitrogen equilibrium on less protein than this (20). The loss of weight in the 2 subjects not in nitrogen equilibrium was greater than could be accounted for by the nitrogen lost, and was probably due in part to mild dehydration associated with periods of diarrhea, particularly since both rapidly gained weight upon return to their normal dietary habits. It is possible that the caloric requirement in these subjects was greater than we supplied, even though they were given a minimum of 3200 calories daily -at least 40 calories per kilogram of body weight.
In contrast to the negative nitrogen balance when a critical level of albumin ( 37.5 grams) was given orally, a positive balance persisted during the intravenous administration of the same amount of albumin. Nitrogen excretion was low and approached the "irreducible minimum," and there was a selective rise in the plasma albumin concentration. Supplementation with tryptophane and isoleucine did not alter the positive nitrogen balance even though approximately 3 grams of the natural isomer of tryptophane was retained during the period of its administration.

Whipple, et al. (13) and Howland and Hawkins (14) found a positive nitrogen balance and an absence of significant nitrogen loss in the urine when plasma was given to dogs intravenously, and an increased excretion of nitrogen when plasma was given orally. They present these results as evidence that the injected plasma is more completely utilized by the body. The authors concluded that injected plasma proteins could replace tissue proteins without being broken down to their constituent amino acids, and suggested a modification of the protein entering the cells by means of a cleavage into large aggregates and reassembly into the normal cell proteins. We suggest an alternative interpretation: Whole protein (albumin) given intavenously to normal individuals diffuses first into the lymphatics where an equilibrium is established. It is then only slowly metabolized, finally breaking down gradually, and probably completely, into its constituent amino acids; these are either deaminated, the nitrogen released then being excreted, or are resynthesized into new tissue protein. The evidence and reasons for this interpretation are presented below.

Parenterally injected albumin and plasma proteins disappear rapidly from the blood stream $(1,21)$, but repeated injections are followed by an appreciable and readily detectable increase in the total circulating plasma proteins, as reported here and by others $(5,10,12)$. It is clear that roughly 24 to 46 per cent of the protein retained in our subjects could be accounted for by the albumin increase in the blood plasma (Table II, column 7). It is likewise apparent that most of the other 54 to 76 per cent was not metabolized promptly and excreted in the urine, as was the case with protein entering the body in a hydrolyzed form (oral albumin and lactalbumin, and intravenous casein 
DEGRAOATION OF SIMGLE AND REPEATED WJECTIONS OF ALBUMIN

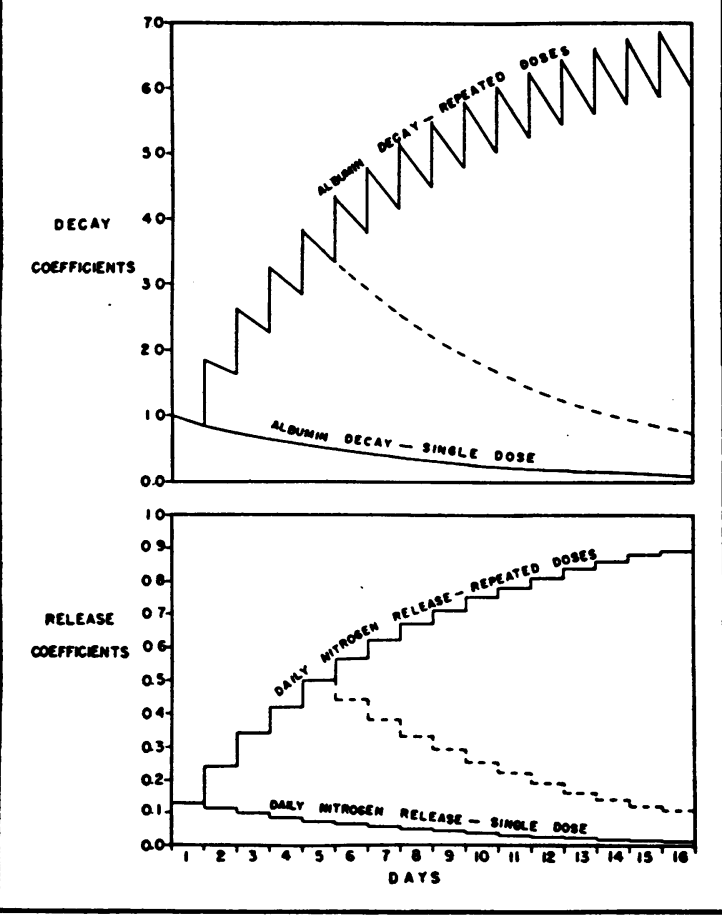

FIG. 9

hydrolysate). Presumably the albumin which left the circulating blood diffused through the capillaries into the interstitial spaces and entered the lymphatic system. The extensive studies of C. K. Drinker demonstrate that serum albumin and serum globulin "are normal constituents of lymph wherever it is collected, and there can be no doubt that they filter from the blood capillaries all over the body" (22). Labeled plasma proteins (23), foreign proteins (24), and dyes that adhere to proteins $(23,24)$ rapidly appear in the thoracic duct lymph after their intravenous injection. Also, the concentration of protein in liver lymph is practically identical to that of plasma (25), and we have observed a patient with a chylothorax in whom the lymph and plasma albumin concentrations were nearly identical (3.0 grams and 3.2 grams per $100 \mathrm{cc}$., respectively). As compared to hepatic and thoracic lymph, the protein content of edema fluid, transudates, and the peripheral lymph is lower, and the diffusion into these fluids of labeled plasma proteins (23) and dyes that adhere to proteins (23) occurs more slowly. Nevertheless, the larger volume of the interstitial and lymphatic fluid as compared to blood plasma could account for most, if not all, of the albumin retained extravascularly in our subjects.

Following injections of radioactive labeled plasma proteins and radioactive dyes that adhere to proteins, Cope and Moore (23) demonstrated that an equilibrium (ratio of radioactivity to protein concentration) was attained between serum and thoracic lymph in about 6 hours, and peripheral (leg) lymph in 17 to 23 hours. Albumin presumably behaves in a similar manner, so that as the albumin concentration increases in the plasma during the period of intravenous albumin administration, that in the lymphatic system likewise rises.

After the albumin injections were discontinued in our subjects, the albumin retained in the plasma disappeared relatively slowly at a "50 per cent disappearance time" of roughly 4 to 6 days (Figure 6), so that return to the control plasma albumin content was not reached until approximately 3 weeks after resuming a normal diet. Others have observed that injected plasma protein and injected antibody protein disappeared from the plasma at a similar rate. Thus Fink et al. (26) injected plasma protein labeled with radioactive lysine into normal dogs. After an initially rapid disappearance from the plasma during the first day, approximately 50 per cent of the remaining labeled plasma protein disappeared in the next 5 days. Likewise, Heidelberger et al. (27) injected antibody protein into rabbits. Of the protein present in the plasma on day 2, 37 and 67 per cent (average 52 per cent) had disappeared by day 7 . Although neither the disappearance from the plasma of labeled plasma protein injected into dogs (26) nor of antibody protein injected into rabbits (27) appeared to be logarithmic, in contrast to the apparent logarithmic disappearance of the retained plasma albumin in our subjects (Figure 6), the similarity is apparent in the rate of disappearance of albumin, plasma protein, and antibody protein from the plasma after intravenous injection. The rate of disappearance of albumin retained in the plasma of our subjects should be a measurable index of the disappearance of the albumin retained in the lymphatic system as well, for their fall will coincide since they are in equilibrium. Thus, the selective rise in the plasma albumin concentration which only slowly returned to the control value, as well as the positive nitrogen balance and mini- 
mum nitrogen excretion in the well-nourished individuals reported here, has led us to believe that albumin administered intravenously is not promptly metabolized but degraded slowly.

To more clearly visualize the process of degradation as we understand it, we have constructed the diagram shown in Figure 9 which was calculated from the general equation of decay. ${ }^{10}$ The diagram shows the quantity of albumin that would remain "unchanged" in the body if albumin were given parenterally on 1 or on successive days, as well as the quantity of nitrogen that would be "released"

10 The authors gratefully acknowledge the assistance of Herbert Jaffe, Ph.D., in the following mathematical interpretation:

(a) Albumin decay-single dose: $A=A_{0} e^{-k t}$, where $A=$ quantity of albumin in body at any time, $t$, after initial dose; $A_{0}=$ quantity (dose) of albumin given initially; $t=$ time in days after initial dose; and $k=0.1386$ ( 50 per cent decay in 5 days). Values plotted in Figure 9 as decay coefficients $\left(\frac{A}{A_{0}}\right)$ where $\frac{A}{A_{0}}=e^{-k t}$. Coefficient at any time, $t$, following initial dose $X$ dose albumin given $=$ quantity of albumin in body at time, $t$.

(b) Daily nitrogen release-single dose: Obtained by subtracting from the quantity of albumin present in body on any day the smaller quantity remaining 1 day later. Plotted as release coefficients, so that the coefficient at any time, $t$, following initial dose $X$ dose albumin nitrogen given $=$ quantity nitrogen released from decay of albumin for that day.

(c) Albumin decay-repeated doses: By an expansion of the general equation of decay (Equation $a$ ), one obtains:

$$
\begin{aligned}
A_{n}=A_{0}\left(e^{-k t^{\prime}}\right)+A_{0}\left(e^{-k t^{\prime}}\right)^{2}+ & A_{0}\left(e^{-k t^{\prime}}\right)^{3}+\cdots \\
& +A_{0}\left(e^{-k t^{\prime}}\right)^{n-1}+A_{0}\left(e^{-k t^{\prime}}\right)^{n},
\end{aligned}
$$

where $A_{n}=$ quantity of albumin present in body after $n$, number doses; $A_{0}=$ quantity (dose) of albumin given initially and repeatedly on multiple dosage schedule; $n=$ number of doses given; $\boldsymbol{t}^{\prime}=$ interval between doses (one day for this experiment). Values plotted as decay coefficients $\left(\frac{A_{n}}{A_{0}}\right)$ where

$\frac{A_{n}}{A_{0}}=\left(e^{-k t^{\prime}}\right)+\left(e^{-k t^{\prime}}\right)^{2}+\left(e^{-k t^{\prime}}\right)^{2}+\cdots$

$$
+\left(e^{-k t^{\prime}}\right)^{n-1}+\left(e^{-k t^{\prime}}\right)^{n} \text {. }
$$

By multiplying the coefficient for any day by the dose of albumin given initially, one obtains the quantity of albumin present in the body on that day.

(d) Daily nitrogen release-repeated doses: Obtained by subtracting from the quantity of albumin present in the body after a dose is given the quantity present prior to giving the next dose (e.g., the amount decayed on that day). Coefficient for any day following initial dose of albumin $X$ dose albumin nitrogen given initially $=$ quantity of nitrogen released from the decay of the albumin present in the body on that day. each day from the degradation of the albumin still remaining in the body. The conditions for the data in Figure 9 are these: (1) The quantity of albumin given once or repeatedly is of equal dosage with equal intervals between doses; and (2) the albumin is assumed to decay at a 50 per cent disappearance time of 5 days (average of values in our subjects, Figure 6). For simplicity of presentation, it is assumed to break down at a constant and uniform rate, even though factors such as the nutritional state of the tissues, the plasma albumin level, the quantity of material injected, and alterations that may occur in the nutritional and physical properties of the albumin during processing might modify both the rapidity of diffusion from the blood stream into the extra-vascular compartments, and the degree and rate of degradation of the protein. Following the single injection of any given quantity of albumin there would be a steadily decreasing amount of albumin remaining "unchanged" in the body on successive days, so that on day 5 only one-half ( 50 per cent) of the original would remain. The quantity of nitrogen "released" from this breakdown of albumin would similarly decrease in amount on each subsequent day. When, however, repeated daily injections of the same dosage of albumin are given for several days, the quantity of albumin remaining "unchanged" in the body would increase in step-like fashion as would the amount of nitrogen "released." Both curves tend to become asymptotic after approximately 2 weeks of daily albumin injections so that the quantity of nitrogen released each day approaches the quantity of albumin nitrogen given daily. The dotted lines in Figure 9 show the decreasing quantities of albumin that would remain in the body and the diminishing amounts of nitrogen that would be released from its decay if albumin injections were discontinued after 5 days.

The question may now be asked: Is the intravenously administered albumin, which we believe is degraded slowly, broken down completely to its constituent amino acids? If it were, the amino acids released from the breakdown of the albumin would be available for deamination and excretion or resynthesis into tissue proteins, the amounts thus "converted" or "burned" depending upon the quantity of amino acids available and the needs of the body for protein. By employing the mathe- 
matical data in Figure 9, it is possible to determine the quantity of nitrogen theoretically "released" in our 2 subjects who received daily the small amount of albumin (6.0 grams nitrogen) intravenously. Under these conditions one would expect to find 0.8 gram of nitrogen released on day $1(0.13 \times 6)$; 3.0 grams on day $5(0.5 \times 6)$; and 4.5 grams on day $10(0.75 \times 6)$. Therefore, when one administers on successive days only small amounts of albumin as a sole source of nitrogen (as in our subjects given 37.5 grams daily), the nitrogen released daily, even after several days, would no more than maintain the body protein requirements even if all of the released amino acids were converted into tissue protein. Thus one would not expect to detect a gradually increasing urinary nitrogen excretion-and, indeed, none was observed in our subjects during the 8 and 16 days of daily intravenous albumin therapy. Nor has Whipple et al. (13) noted a significantly increased nitrogen excretion in dogs receiving only moderate amounts of plasma intravenously as the sole source of nitrogen. However, had Whipple's basal diets contained adequate protein to fulfill the minimum nitrogen requirements, or had large quantities of plasma been given by vein, one might well have observed an increased nitrogen excretion. Indeed, when a constant oral diet containing at least 50 grams of protein was given by Albright (11) to his patients, an increased urinary excretion of nitrogen was observed by about the third day after plasma injections, and was not complete in the subsequent 1 to 3 weeks. Under these conditions, the oral nitrogen could be considered to fulfill the body protein requirements, the nitrogen "released" from the decay of the injected plasma protein would be "extra," and that quantity of nitrogen would appear in the urine. Furthermore, when large quantities of plasma protein were administered intravenously by Meyer et al. (12) to patients, and by Elman and Davey (10) to dogs, both groups noted a subsequent rise in the urinary nitrogen excretion resulting in an "apparent" negative nitrogen balance. The results of the latter investigators however, have been questioned since citrate was used as the anti-coagulant (28). The parenteral administration of large amounts of plasma as the sole source of nitrogen is analogous to small or moderate amounts of plasma plus a quantity of dietary protein which in itself could fulfill the body protein needs. The most plausible explanation for the observed increase in urine nitrogen (shown by Meyer [12] to be non-protein-non-peptide nitrogen by nitrogen partition) that follows intravenous plasma administration is that the retained plasma protein is subsequently broken down to amino acids which, if present in excess of the body protein requirements, are then deaminated and the released nitrogen excreted. The critical observations of Albright (11) that "conversion" and "burning" of injected plasma protein do not start to an appreciable degree until several days after the plasma protein injections is readily explained by this hypothesis, for several days must elapse before the degradation of the injected plasma has released sufficient amino acids for resynthesis into tissue protein, and for those released in excess of these requirements to be deaminated and excreted in the urine.

Further evidence that the body less readily uses conjugated than "free" amino acids is found in the work of Christensen, Lynch, and Powers (29). These authors recently observed that in 3 to 6 hours following the intravenous administration of a partial protein hydrolysate ("Amigen") the plasma elevation of conjugated amino acids (polypeptides) was larger and more prolonged than that of free amino acids, despite the fact that two-thirds of the amino acids in this hydrolysate appeared to be free. Concomitantly only 2.4 to 6 per cent of the "free" alpha amino nitrogen administered appeared in the urine as contrasted to 36 to 53 per cent of that administered as "bound diffusible" (polypeptide) nitrogen. Our figures (in subject W. C.) are in agreement with these and suggest that most of the 1.3 grams of polypeptide amino nitrogen excreted came from the protein hydrolysate administered. These observations indicate that the polypeptides present in partially hydrolyzed protein given intravenously resemble albumin in that they are not promptly metabolized. In contrast to albumin, however, and probably due to their low molecular weight they are largely excreted in the urine rather than being primarily retained in the body. Considering the small loss of "free" alpha amino nitrogen following the intravenous administration of this hydrolysate, one might expect a completely hydrolyzed protein to be of greater nutritional value than a partially hydrolyzed protein. 
Since parenterally administered albumin and plasma proteins are neither rapidly metabolized in the body nor excreted as such by the normal kidney, a positive nitrogen balance (as measured in terms of what goes in and what comes out) is practically inevitable, and can occur even in the "catabolic period" following injury. ${ }^{11}$

Although not immediately available as a protein nutrient, adequate quantities of injected albumin and plasma can serve as a delayed nutrient, entering into the metabolic pool only slowly where they presumably fulfill all the body protein requirements. In fact, Whipple (30) has shown that dogs receiving plasma intravenously as the sole source of nitrogen have remained in perfect health for more than 3 months. Because of the slow and gradual release of amino acids from injected whole protein, more "efficient" utilization may occur, particularly when one considers this utilization extending over days instead of hours which is the case when the protein is orally ingested. Albright observed (11) that a portion of the retained plasma protein is eventually converted into tissue protein in the face of a constant oral diet which in itself contains adequate protein to maintain nitrogen equilibrium. This suggests that whole protein parenterally injected may actually increase the amount of body tissue normally formed.

\section{SUMMARY}

Normal human serum albumin was administered orally or intravenously to 5 normal individuals as a sole source of nitrogen for periods of from 7 to 16 days. Nitrogen balance and plasma protein concentration were studied and the effects of the administered albumin compared in each instance with those obtained with intravenous casein hydrolysate, oral lactalbumin, or oral human albumin.

Albumin administered orally in small amounts ( 37.5 grams daily) to 2 individuals failed to main-

11 The "inevitable" positive nitrogen balance will occur only when the quantity of whole protein nitrogen injected exceeds the loss of nitrogen in the urine that would occur on a protein-free diet. Thus, one would anticipate a negative balance if but 10 grams of albumin were given to a subject whose endogenous urinary loss exceeded 1.6 grams of nitrogen daily, or if 100 grams of albumin were given to a patient whose catabolic urinary excretion was greater than 16 grams of nitrogen daily. tain nitrogen equilibrium itself or when supplemented with tryptophane and isoleucine. The lactalbumin preparation in the same amount also failed to maintain nitrogen equilibrium. There was no significant change in concentration of plasma proteins in this study.

Albumin administered orally in a larger quantity (50.0 grams daily) to 1 individual maintained weight and nitrogen balance, even though the albumin was not supplemented with tryptophane or isoleucine. Albumin in adequate amounts, therefore, contains all the essential amino acids required by man for maintenance of nitrogen balance.

The intravenously administered partial protein hydrolysate maintained a slightly positive nitrogen balance for very short periods of time and was associated in 1 subject with the excretion in the urine of 46 per cent of the polypeptide administered.

Albumin administered intravenously in small amounts (37.5 grams daily) maintained a positive nitrogen balance for 8 and 16 days in 2 individuals, and was associated with a selective rise in plasma albumin concentration. There was no significant difference in nitrogen balance when the albumin was supplemented with tryptophane or isoleucine.

Albumin administered intravenously in large amounts (75 grams daily) to 1 individual for 4 days produced a very marked positive nitrogen balance with minimum nitrogen excretion. This was in contrast to the effect of intravenous casein hydrolysate in a previous period and of albumin administered orally in a subsequent period, during both of which the nitrogen excretion approached the intake. The plasma albumin concentration rose 1.72 grams to an abnormally high level (6.12 grams per $100 \mathrm{cc}$.) during the period of intravenous albumin administration.

After the intravenous injections of albumin were discontinued in 2 subjects, the albumin retained in the plasma disappeared at a 50 per cent disappearance time of 4 to 6 days, so that by 3 weeks the level had fallen to nearly the original value.

The following mechanism for the metabolism of intravenously administered albumin in normal man would appear to explain the observations presented here and those of other investigators: When albumin is administered intravenously it 
rapidly disappears from the plasma by diffusion into the lymphatic system, and an equilibrium or balance between the vascular and extra-vascular albumin is soon established. After repeated injections there is an increase in the total plasma albumin and the lymphatic albumin. After the albumin infusions are discontinued there is a disappearance of the albumin retained in the plasma which is an index of the rate of disappearance of the albumin retained in a state of balance in both the vascular and extra-vascular compartments. The albumin which is retained in the body disappears by a process of degradation or decay by which nitrogen is released as amino acids. The amino acids released from the slow breakdown of albumin are either resynthesized into tissue protein or deaminated and excreted in the urine as non-protein nitrogen, the amounts thus "con- verted" or "burned" depending upon the needs of the body for protein and the quantity of amino acids released. A positive nitrogen balance will occur when albumin is given intravenously since the albumin is neither excreted by the normal kidney nor rapidly metabolized in the body. Parenterally administered albumin can serve as a body protein nutrient, and perhaps a very good one, but its action is delayed, entering into the metabolic pool only slowly, as contrasted to protein which enters the body in a hydrolyzed form. It is because of the properties that tend for slowness of utilization that albumin is an ideal substance for temporarily increasing the plasma albumin concentration and the oncotic pressure of the blood.

\section{ACKNOWLEDGMENTS}

The authors wish to thank Margaret A. Adams, Alice N. Ballou, Virginia Garrison and Mary A. Maloney for their technical assistance, and Jean V. Harrison for preparing and calculating the diets used.

\section{BIBLIOGRAPHY}

1. Janeway, C. A., Gibson, S. T., Woodruff, L. M., Heyl, J. T., Bailey, O. T., and Newhouser, L. R., Chemical, clinical and immunological studies on the products of human plasma fractionation. VII. Concentrated human serum albumin. J. Clin. Invest., 1944, 23, 465.

2. Cournand, A., Noble, R. P., Breed, E. S., Lauson, H. D., Baldwin, E. DeF., Pinchot, G. B., and Richards, D. W. Jr., Chemical, clinical, and immunological studies on the products of human plasma fractionation. VIII. Clinical use of con- centrated human serum albumin in shock, and comparison with whole blood and with rapid saline infusion. J. Clin. Invest., 1944, 23, 491.

3. Warren, J. V., Stead, E. A., Jr., Merrill, A. J., and Brannon, E. S., Chemical, clinical, and immunological studies on the products of human plasma fractionation. IX. The treatment of shock with concentrated human serum albumin: a preliminary report. J. Clin. Invest., 1944, 23, 506.

4. Thorn, G. W., Armstrong, S. H., Davenport, V. D., Woodruff, L. M., and Tyler, F. H., Chemical, clinical, and immunological studies on the products of human plasma fractionation. XXX. The use of salt-poor concentrated human serum albumin solution in the treatment of chronic Bright's disease. J. Clin. Invest., 1945, 24, 802.

5. Thorn, G. W., Armstrong, S. H., and Davenport, V. D., Chemical, clinical, and immunological studies on the products of human plasma fractionation. XXXI. The use of salt-poor concentrated human serum albumin solution in the treatment of hepatic cirrhosis. J. Clin. Invest., 1946, 25, 304.

6. Brand, E., Kassell, B., and Saidel, L. T., Chemical, clinical, and immunological studies on the products of human plasma fractionation. III. Amino acid composition of plasma proteins. J. Clin. Invest., 1944, 23, 437.

7. Hegsted, D. M., Hay, A. L., and Stare, F. J., Chemical, clinical, and immunological studies on the products of human plasma fractionation. XXIV. Studies on the nutritive value of human plasma fractions. J. Clin. Invest., 1945, 24, 657.

8. Rose, W. C., Progress in conquest of malnutrition by amino acids. Sixth Annual Scientific Award Ceremony of the American 'Pharmaceutical Manufacturers' Association, New York, 1944.

9. Browne, J. S. L., Schenker, V., and Stevenson, J. A. F., Some metabolic aspects of damage and convalescence. J. Clin. Invest., 1944, 23, 932.

10. Elman, R., and Davey, H. W., Studies on hypoalbuminemia produced by protein-deficient diets. III. The correction of hypoalbuminemia in dogs by means of large plasma transfusions. J. Exper. Med., 1943, 77, 1.

11. Albright, F., Personal Communication.

12. Meyer, F. L., Hirshfeld, J. W., Abbott, W. E., Pilling, M. A., Williams, H. H. and Richards, A. J., Nitrogen balance and blood volume studies in mian during and following repeated plasma transfusions. Am. J. Med. Sc., 1947, 213, 160.

13. Whipple, G. H., and Madden, S. C., Hemoglobin, plasma protein and cell protein: their interchange and construction in emergencies. Medicine, 1944, 23, 215.

14. Howland, J. W., and Hawkins, W. B., Protein metabolism, protein interchange, and utilization in phlorhizinized dogs. J. Biol. Chem., 1938, 123, 99.

15. Howe, P. E., The use of sodium sulphate as the globulin precipitant in the determination of proteins in the blood. J. Biol. Chem., 1921, 49, 193. 
16. Gregersen, M. I., A practical method for the determination of blood volume with the dye T-1824. A survey of the present basis of the dye method and its clinical application. J. Lab. \& Clin. Med., 1944, 29, 1266.

17. Shaw, J. L. D., and McFarlane, W. D., The determination of tryptophane by a modified glyoxylic acid method employing photo-electric colorimetry. J. Cancer Research, 1938, 16B, 361.

18. Van Slyke, D. D., MacFadyen, D. A., and Hamilton, P. B., The gasometric determination of amino acids in urine by the ninhydrin-carbon dioxide method. J. Biol. Chem., 1943, 150, 251.

19. Peters, J. P., and Van Slyke, D. D., Quantitative Clinical Chemistry. Interpretations. Baltimore, 1946, Volume I, Ed. 2, p. 656.

20. Stare, F. J., Hegsted, D. M.; and McKibbin, J. M., Nutrition. Ann. Rev. Biochem., 1945, 14, 431.

21. Metcalf, W., The fate and effects of transfused serum or plasma in normal dogs. J. Clin. Invest., 1944, 23, 403.

22. Drinker, C. K., The formation and movement of lymph. (The George Brown Memorial Lecture.) Am. Heart J., 1939, 18, 389.

23. Cope, O., and Moore, F. D., A study of capillary permeability in experimental burns and burn shock using radioactive dyes in blood and lymph. $\mathrm{J}$. Clin. Invest., 1944, 23, 241.
24. Ferrebee, J. W., Leigh, O. C., and Berliner, R. W., Passage of the blue dye T-1824 from the blood stream into the lymph. Proc. Soc. Exper. Biol. \& Med., 1941, 46, 549.

25. McCarrell, J. D., Thayer, S., and Drinker, C. K., The lymph drainage of the gall bladder together with observations on the composition of liver lymph. Am. J. Physiol., 1941, 133, 79.

26. Fink, R. M., Enns, T., Kimball, C. P., Silberstein, H. E., Bale, W. F., Madden, S. C., and Whipple, G. H., Plasma protein metabolism: normal and associated with shock. Observations using protein labeled by heavy nitrogen in lysine. J. Exper. Med., 1944, 80, 455.

27. Heidelberger, M., Treffers, H. P., Schoenheimer, R., Ratner, S., and Rittenberg, D., Behavior of antibody protein toward dietary nitrogen in active and passive immunity. J. Biol. Chem., 1942, 144, 555.

28. Whipple, G. H., Letter to the Editor. Nutrit. Rev., 1945, 3, 255.

29. Christensen, H. N., Lynch, E. L., and Powers, J. H., The conjugated, non-protein, amino acids of plasma. III. Peptidemia and hyperpeptiduria as a result of the intravenous administration of partially hydrolyzed casein (amigen). J. Biol. Chem., 1946, 166, 649.

30. Whipple, G. H., Personal Communication. 